Témoigner Témoigner. Entre histoire et mémoire

Getuigen Revue pluridisciplinaire de la Fondation Auschwitz

$122 \mid 2016$

Révisionisme et négationisme

\title{
Memorial representations in Peru: The voluntary defence of human rights for the convening of the arts
}

Représentations mémorielles au Pérou: de la défense associative des droits de l'homme à la convocation des arts

\section{Mylène Herry}

Translator. Jennie Malcolm

\section{(2) OpenEdition} Journals

Electronic version

URL: https://journals.openedition.org/temoigner/4920

DOI: $10.4000 /$ temoigner.4920

ISSN: 2506-6390

This article is a translation of:

Représentations mémorielles au Pérou : de la défense associative des droits de l'homme à

la convocation des arts - URL : https://journals.openedition.org/temoigner/4863 [fr]

Publisher:

Éditions du Centre d'études et de documentation Mémoire d'Auschwitz, Éditions Kimé

Printed version

Date of publication: 2 May 2016

Number of pages: 169-175

ISSN: 2031-4183

Electronic reference

Mylène Herry, "Memorial representations in Peru: The voluntary defence of human rights for

the convening of the arts", Témoigner. Entre histoire et mémoire [Online], 122 | 2016, Online since 30

September 2021, connection on 03 February 2022. URL: http://journals.openedition.org/temoigner/ 4920 ; DOI: https://doi.org/10.4000/temoigner.4920 


\section{Memorial site}

\section{MEMORIAL \\ REPRESENTATIONS IN PERU: \\ THE VOLUNTARY DEFENCE \\ OF HUMAN RIGHTS FOR THE \\ CONVENING OF THE ARTS}

$\mathrm{n}$ this section devoted to memorial sites, I would like to enlarge on the representation of memory in contemporary Peru, a subject introduced in the previous issue where I discussed $E l$ ojo que llora (The Eye That Cries), the emblematic monument erected in Lima in 2005. Peru is a country that has suffered for two decades (1980-2000) from extremely violent internal conflicts. In this respect, it is important to note the delaybetween, on the one hand, the time of the war and, on the other, the moment of 'truth', when the facts were acknowledged and the phase of testimonial transmission was inaugurated, among others, by the CVR [Truth and Reconciliation Commission] in 2001. It was from this point that historical Truth emerged, driven by direct witnesses of atrocities and the Andean peasants, people without a voice, mostly victims of political and racial violence. The official story promoted by the state until then was revisited and corrected in the hope of building a collective memory. Memorial representations, whether artistic, associative, architectural or cultural, were aimed at national repair. However, tensions arose because beliefs, fears, resentments and regrets clashed with individual choices that people made during the conflict. In this sense, El ojo que llora, as we have seen, is both an example of an appeal to national communion stemming from a legacy project, and an example of the rejection of this communion, crystallized by national tensions around the responsibility and legitimacy of the authorities and of the Communist Party the Shining Path.
A general overview of memorial representations in post-conflict Peru will be given, considering the diverse fields involved. In particular, I will present the National Association of Families of the Condemned, Detained and Disappeared of Peru (ANFASEP) which was created in 1983 in Ayacucho, the Andean city and region hardest hit during the armed conflict. I will mention some very iconic memorial places of this period and this geographic area that are frequently represented in the oral literature. Also, I will discuss the work of Para que no se Repita (Never again), a civil association working to combat the oblivion and the injustices suffered during and since that dark period of Peruvian history. Finally, I will give an overview of cultural spaces devoted to the internal conflict. 
Meeting room of ANFASEP in Ayacucho Ground floor: former "Comedor de niños" -

Exhibition room with objects that belonged to the victims (Museum of Memory) -

Drawing on the inside wall of the room.

\section{AYACUCHO - ANFASEP}

ANFASEP was created on 2 September 1983 in Ayacucho and was previously called the Disappeared Families Committee (CFD). It is an extension of APRODEH (Asociación Pro Derechos Humanos/Association for Human Rights) based in Lima and engaged in the promotion and protection of human rights in Peru. While insecurity was at its peak at the beginning of the conflict, "Mamá Angelica”, aka Angélica Mendoza de Ascarza, decided to create this association following numerous complaints of unexplained disappearances, including that of her son. This association, ahead of its time in facing rising violence, brings together around 350 members in the struggle to locate the hostages and recover the bodies of victims. The testimonies highlight the abuse of authority and a denial of human rights. ANFASEP became a place of gathering, confession and sharing for all those who, in one way or another, suffered the trauma of the internal war.

In 1985, to meet the growing number of war orphans, a canteen opened on the premises. It was called "Comedor de niños Adolfo Pérez Esquivel” (Children's room of Adolfo Pérez Esquivel) in honor of its godfather, winner of the Nobel

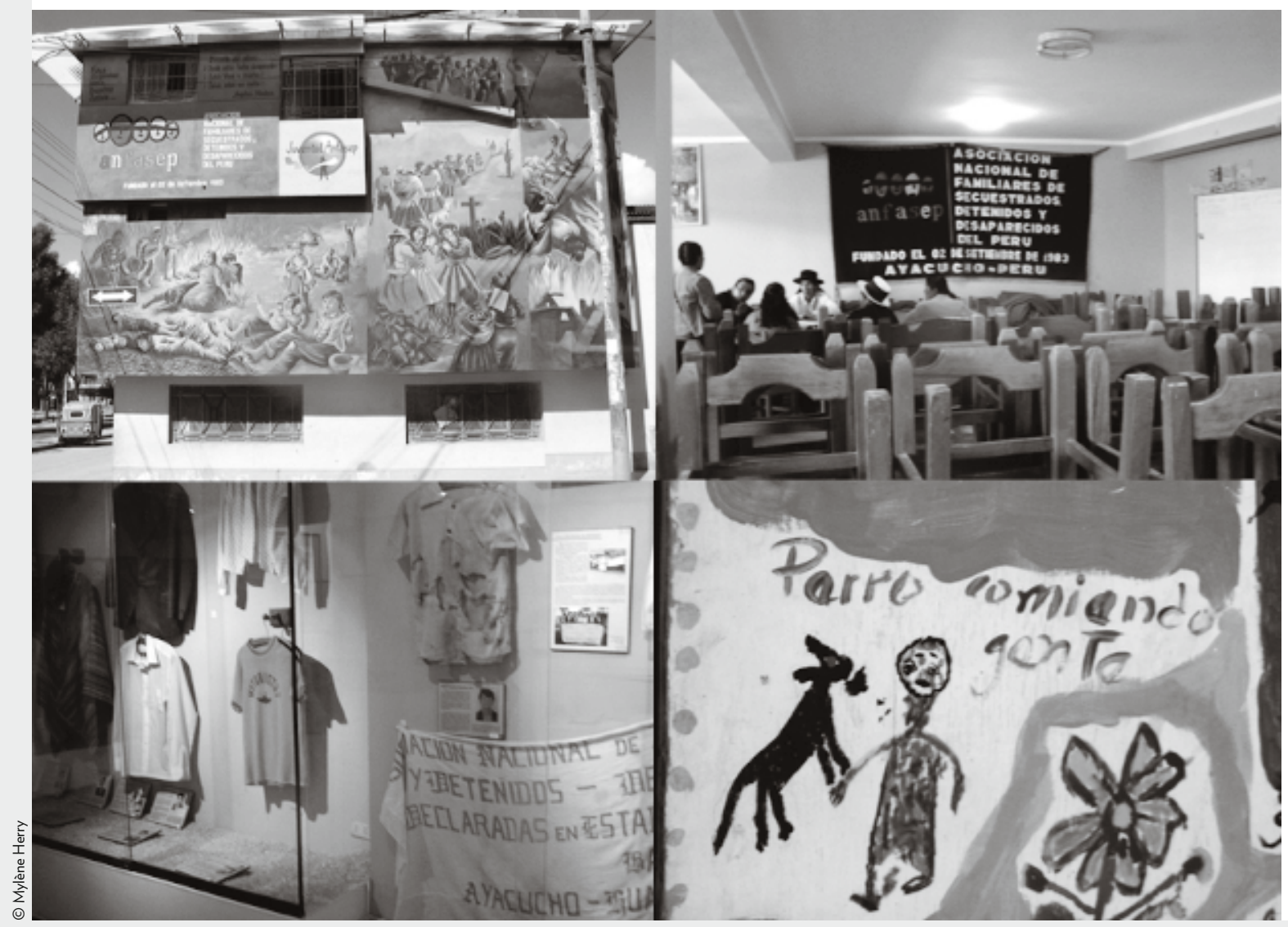


Peace Prize. It closed in 1996 following a growing budget deficit.

Two years after the publication of the Final Report of the TRC in 2005 and thanks to institutional and community support, the Museum of Memory was created on the third floor of the ANFASEP building. It is organized into three areas: the area of the "chaos" proposing accounts of the years of terror and a historical reconstruction of the period; a photo exhibition area containing objects and personal affairs of the disappeared; and one last area that presents photos of members of the association, mostly lone women following the disappearance of their husbands and/or their children. Frescoes of nine meters by six cover the exterior walls of the building and depict scenes of political violence. They were designed by Claudio Martinez, artist of the School of Fine Arts Guamán Felipe Poma de Ayala Ayacucho. There are also pictures of the missing on the façade, victims' names carved onto some stones at the entrance of the museum - the Sanctuary of ANFASEP - and also a memorial park and totem pole (all built in 2005) in the adjacent square. These memorial expressions testify to the violent past of the region and the wish of the population to recognize it. For example, the iron monument that represents the totem of memory has three sides symbolizing the violent past of a population caught up in the conflict, a still unbalanced judicial presence, and a future represented by a dove and two hands that are about to reconcile. Also, the opening of the museum craft shop in 2006 and the production of numerous "retablos" depicting that period, help to diffuse the message of the association and, therefore, activate collective memory.

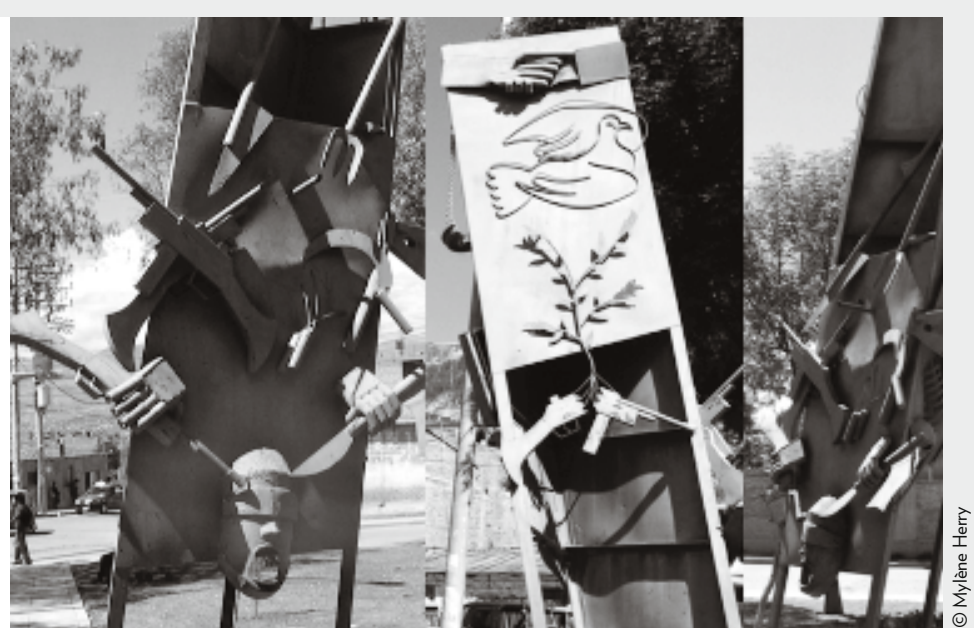

\section{AYACUCHO}

In Huamanga-Ayacucho, the many vestiges of the 1980s recall, first, the strong presence of Marxist ideology in the former university district and, second, the violent nature of the conflict (remains of burnt or blown up buildings). This place is symbolic, considering the role played by universities throughout the conflict. By the late 1970s, the Shining Path started to recruit people at universities and educational institutes, paving the way for ideological influence in the next decade. The student population was very active and often supported the popular revolution. In retaliation, until the end of the Fujimori government, the military regularly intervened. Some of these interventions were symbolic, for example when the image of Che on the front of the Law School of San Marcos (Lima) was erased, but some were barbaric: on 18 July 1992, a paramilitary group known as the "Colina" held nine students and a professor hostage from the University Enrique Guzmán y Valle, La Cantuta. Their bodies were found a year later in a mass grave in Cieneguilla (Lima).
The totem pole of memory Ayacucho. 


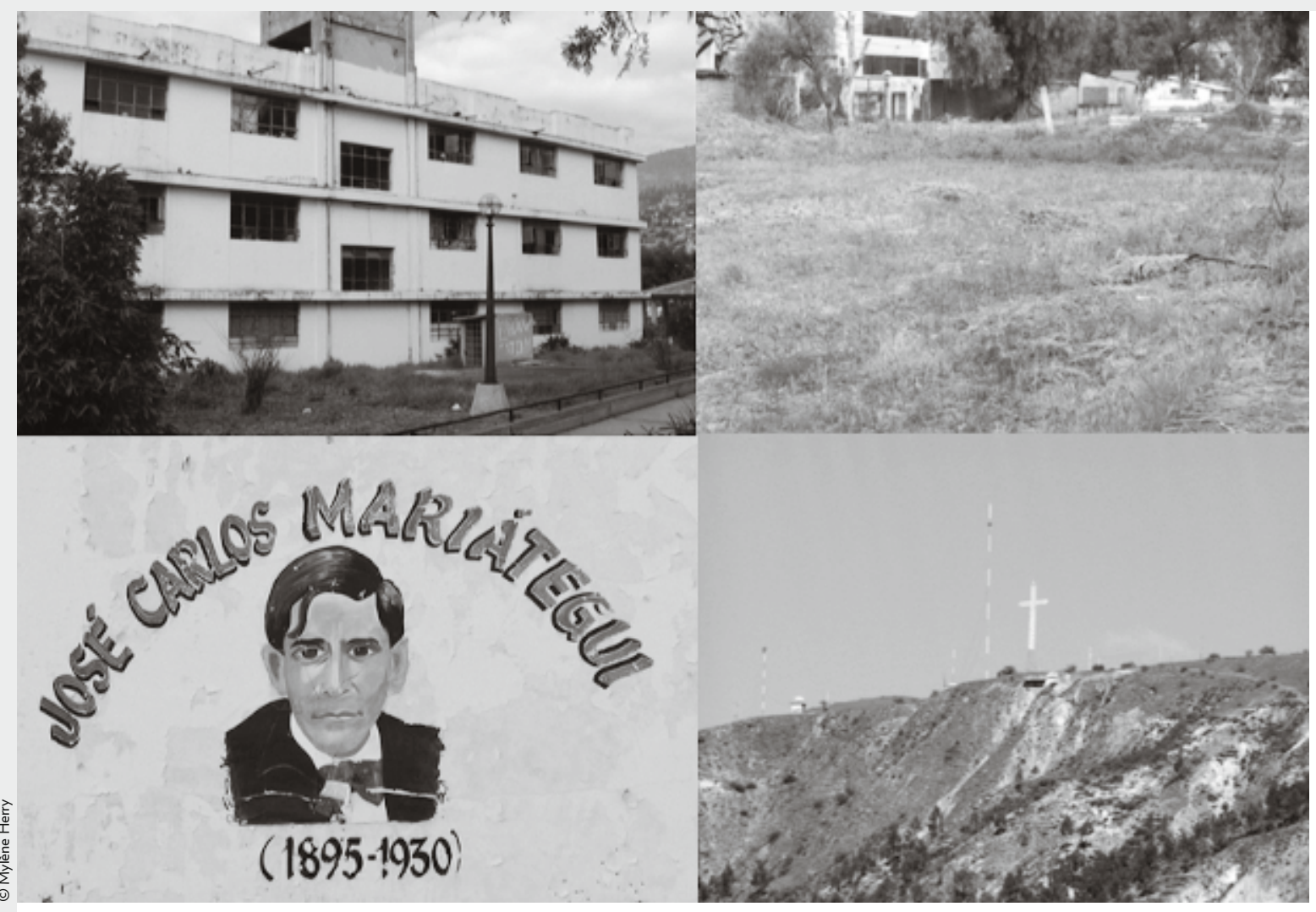

Remains of the former University of Huamanga. The buildings still carry the names of important communist leaders - Cruz de la Paz.
- Similarly, the "Cruz de la Paz" [Cross of Peace], symbol of the city, was built in 2011 on El Cerro de la Picota, on the initiative of the municipality. Constructed with the remains of electrical towers destroyed in the conflict, it overlooks the city and is illuminated every evening at 18 hours, remembering the fires of the Peruvian Communist Party Shining Path who, from these hills, imposed a curfew, plunging the city into darkness. More recently, in July 2011, the "Cruz de la Hoyada" was unveiled on the site of the former barracks of Los Cabitos in Ayacucho, in memory of the victims. The term refers to mass graves found in this location as well as to the cremation of bodies in furnaces.
Since the release of the CVR's report, literature has attempted to reinvest these places, which have become the setting for a crime novel (Abril rojo, 2007), the poetic inspiration of witness accounts (Rocio Silva Santisteban, Las hijas del terror, 2005) and the model for an artistic and graphic representation of facts (Jesús Cossio, Rupay, 2008, and Barbary, 2010). Peruvian literature thus offers a space where witnesses' voices can resonate and even inform textual structures, giving rise to genre hybridity and testimonial interdiscursivity. In Rupay, for example, the story is interspersed with photographic material that serves as proof and confirms the CVR report. 

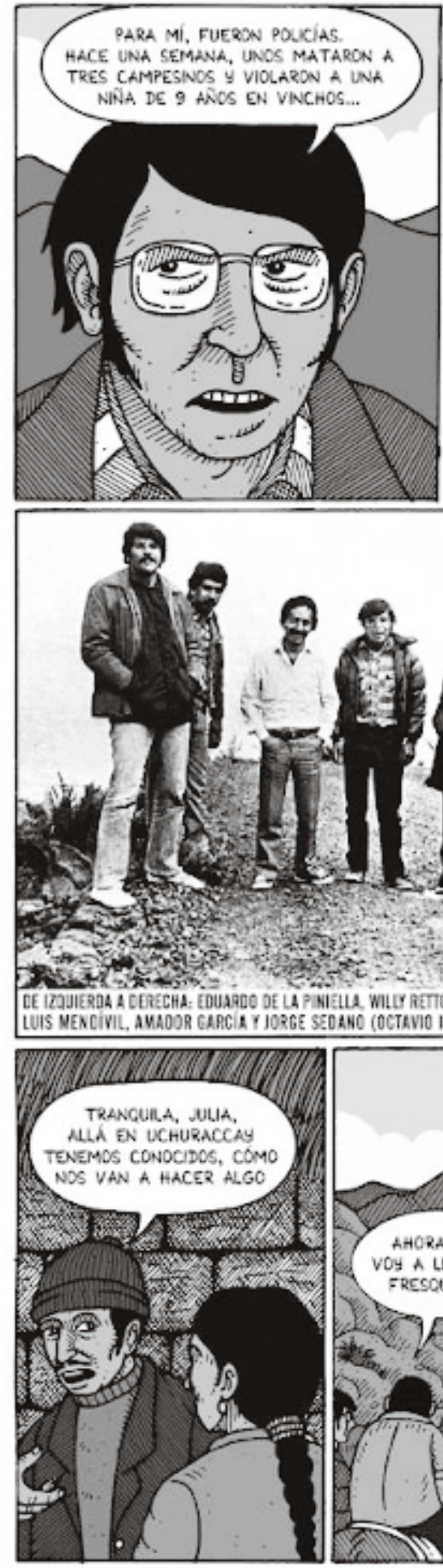
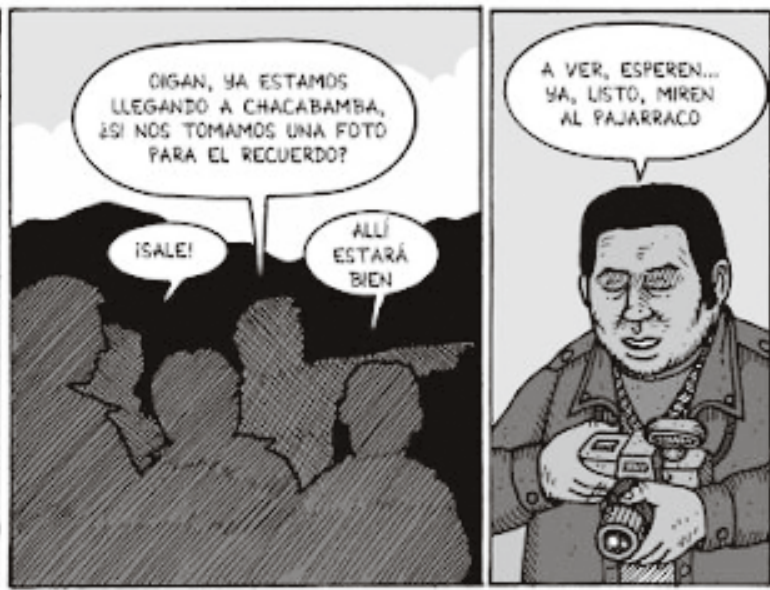

EN CHRCABAMBa, INFANTE CONVECE A SI HEDIO HERMENO ILAN ARCUMEDO FRRA CUE LOS GUIE HASTA LCRURACCAY. LA FAMILU DE AFGL HEDO LES DR DE COUER Y LES PRESTA NANTAS Y UNA MULA PAPA CLFCRR CAVERAS $Y$ EULTCS.
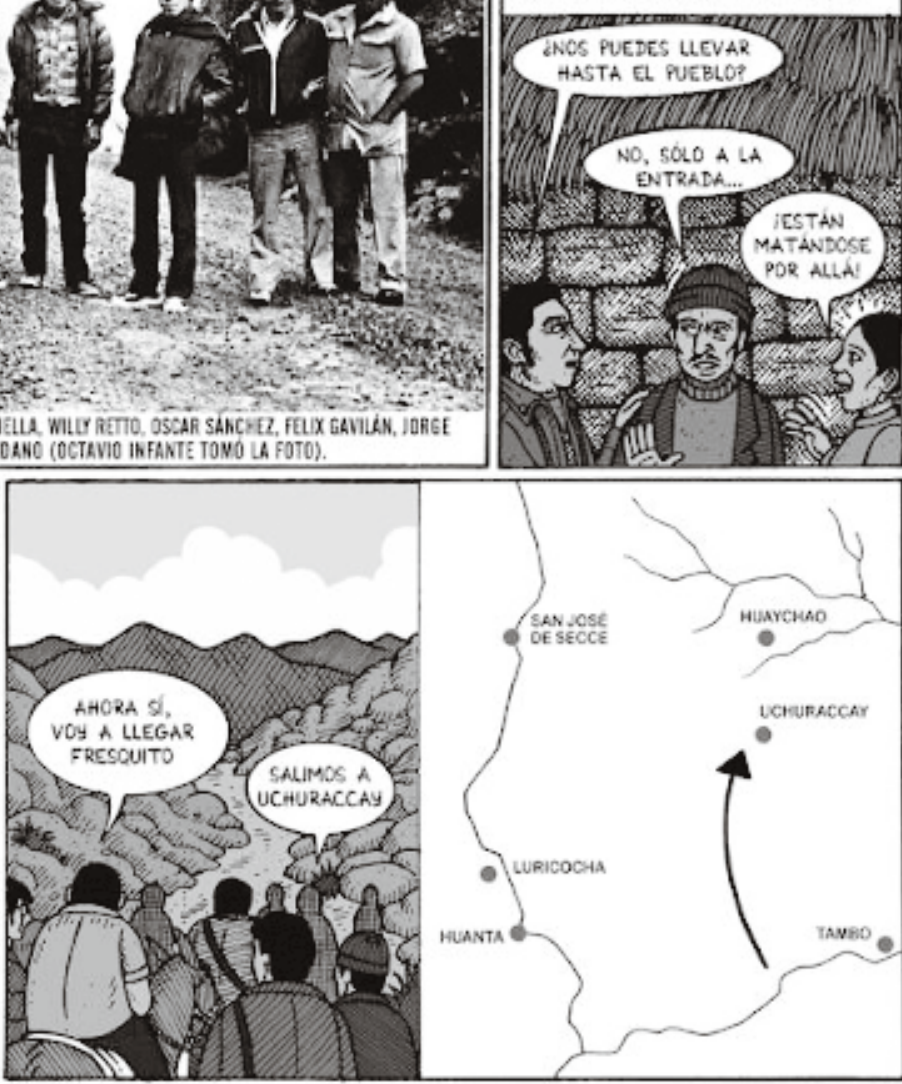

$\rightarrow$ Page of Rupay containing, as a journalistic and didactic reference but also as a form of testimony, a photo of the eight journalists killed in Uchuraccay. 


\section{PARA QUE NO SE REPITA}

The Citizens' Association Para que no se Repita, established in 2004, monitors the development and implementation of the CVR's recommendations. It consists of over 400 human rights organizations and community groups in 25 regions of the country who work in the field. Its goal is to organize commemorations and build memorials for victims and survivors. With National campaigns revolving around education, human rights, youth, and means of communication, the organization strives for National Reconciliation and a future society without violence or exclusion.

\section{CONVENING THE IMAGE}

The Yuyanapaq exhibition on the sixth floor of the Museum of the Nation in Lima depicts the history of the Peruvian internal conflict through 182 photographs taken by the CVR during its investigations. The subsequent publication of the photographic story of the years of terror seems to be a powerful instrument against forgetfulness. But more and more artistic events engage with Peru's dark period. In 2008, Santiago Quintanilla inaugurated a graphic art gallery (lo mejor está por venir, the best is yet to come) which includes hybrid works (fiction/reality) created from national newspapers and comic books, and put in chronological order.

Since 2009, El museo virtual de arte y memoria [The Virtual Museum of Art and Memory] has been a mine of information on new publications, exhibitions, films or projects on art and memory. Karen Bernedo Morales, director of this virtual space, provides not only national and international news around cultural or artistic expressions of memory, but also, through a list of articles and bibliographical references, she offers a space for research in memory studies.

In Lima-Miraflores, El Lugar de la Memoria del Perú [The Place of Peruvian Remembrance] will be a museum in tribute to victims of the armed conflict, largely financed by the German government which, after its visit in 2008, made a donation of two million euros to support the construction and maintenance of a museum of memory. Since October 2010, the Alto Nivel Commission charged with the organization is chaired by the Peruvian painter Fer- campaign of Para que no se repita.

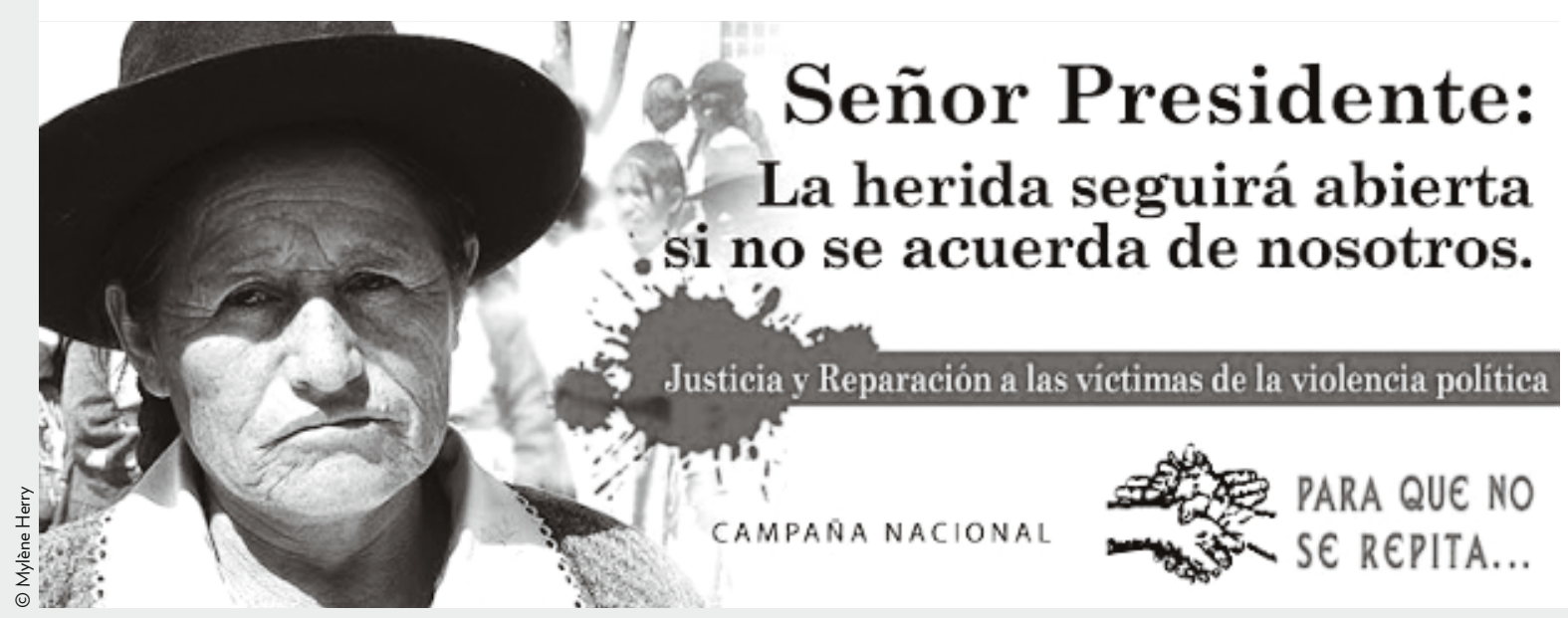


nando de Szyszlo, successor to Mario Vargas Llosa. One site was set up recently under the name Lugar de la Memoria, la Tolerancia y la Inclusión Social [Place of Memory, Tolerance and Social Inclusion] (LUM) on a plot of seven hectares along the coast from the San Martín region to Miraflores. Today director Denise Ledgard and the organizing committee (Víctor Vich, Ponciano del Pino, Jorge Villacorta and Natalia Iguiñiz) discuss the participatory process, whose main axes are presented in a book titled Los fundamentos conceptual del LUM [The conceptual foundations of the LUM] published in 2015. The site is now open for visitors.

All these initiatives are a form of testimony or tribute to the victims and families of the years of terror. The aim is to reconcile people through the spread of information and the building of a collective memory around a long-hidden, and sometimes still denied, past.

\section{Mylène Herry}

Université Toulouse II le Mirail

Translation: Jennie Malcolm

\section{$\rightarrow$ Learn more}

ANFASEP, http://www.anfasep.org/anfasep/index.php?cmbldioma=es (accessed 5 December 2011).

$\rightarrow$ ANFASEP, ¿Hasta cuándo tu silencio? testimonios de dolor y coraje, Lima, 2007.

$\rightarrow$ APRODEH, El reto de la verdad y la justicia: Perú, 1980-2000, Lima, 2001.

APRODEH, Verdad, memoria, justicia y reconciliación: sociedady comisiones de la verdad, Lima, 2002.

Boletín Educación Sin Fronteras 18, special issue on 'Yuyanapaq - para recordar 1980-2000. Relato visual del conflicto armado interno en el Perú, Lima, 1995, www.educacionsinfronteras.org (accessed 2 May 2010).

$\rightarrow$ Comisión de la verdad y reconciliación, Yuyanapaq: para recordar, Relato visual del conflicto armado interno en el Perú (1980-2000), Lima: PUCP, 2003.

Edilberto, Jiménez Quispe, Chungui: violencia y trazos de memoria, Lima: COMISEDH, 2005.

$\rightarrow$ Hatun, Willakuy, Versión abreviada del informe final de la Comisión de la Verdad y Re-conciliación, IDEHPUCP, ICTJ, Universidad de Notre Dame, 2014, http://idehpucp.pucp.edu.pe/tipo/hatun-willakuy/ (accessed 8 December 2015).

Museo virtual de arte y memoria, http://www.museoarteporlasmemorias.pe/ category/tags/per\%C3\%BA (accessed 7 October 2015).

$\rightarrow$ Para que no se repita, http://www.paraquenoserepita.org.pe/ (accessed 5 December 2011).

$\rightarrow$ Ponciano Del Pino, José \& Carlos Agüero, Cada uno, un lugar de memoria Fundamentos Con-ceptuales del Lugar de la Memoria, la Tolerancia y la Inclusion Social, Lima: LUM, 2014, http://lugardelamemoria.org/wp-content/ uploads/2015/01/LIBRO-LUM.pdf (accessed 7 October 2015).

\author{
$\rightarrow$ Works Cited \\ Cossío, Jesús, Barbary, Lima: Contracultura, 2010. \\ Roncagliolo, Santiago, Abril rojo, Madrid: Alfaguara, 2007. \\ Rossell, Luis, Alfredo Villar \& Jesús Cossío, Rupay, Lima: La oveja roja, \\ 2009.
}

Silva Santisteban, Rocío, Las hijas del terror, Lima: Copé, 2007. 